\title{
Framing the Role of Leader: How Community College Presidents Construct Their Leadership
}

Pamela L. Eddy

College of William \& Mary, pamela.eddy@wm.edu

Follow this and additional works at: https://scholarworks.wm.edu/articles

Part of the Community College Leadership Commons, and the Educational Leadership Commons

\section{Recommended Citation}

Eddy, Pamela L., "Framing the Role of Leader: How Community College Presidents Construct Their Leadership" (2005). Articles. 55.

https://scholarworks.wm.edu/articles/55

This Article is brought to you for free and open access by W\&M ScholarWorks. It has been accepted for inclusion in Articles by an authorized administrator of W\&M ScholarWorks. For more information, please contact scholarworks@wm.edu. 


\section{Framing the Role of Leader: How Community College Presidents Construct Their Leadership}

Presidents are one of the most studied of administrative roles. Higher education literature includes reviews of the historic progression of leadership theories (Birnbaum, Bensimon, \& Neumann, 1991), leadership from the vantage point of sitting presidents (Saenz, 1996; Tsunoda, 2001), viewing leaders using a gender perspective (Amey \& Twombly, 1991; Gillett-Karam, 2001; Glazer-Raymo, 1999; Nidiferr, 2002), and by institutional type (Birnbaum, 1992; Coates, 1992; Roueche, Baker, \& Rose, 1989; Vaughan, 1989). The organizational location of the college president at the top of the hierarchy affords individuals in the position a certain amount of power (Fischer, 1984), but presidents wield this power differently based on their cognitive orientation (Eddy, 2003a), institutional culture (Blevins, 2001), and external constraints (Pfeffer, 1991). During times of fiscal exigency, power tends to center with the president (Leslie \& Fretwell, 1996). Historically, state and federal budget reductions and student tuition increases at colleges and universities (Arnone, 2003) resulted in campuses "hunkering down" (Lovett, 2002, p. B12), making the role of the college president even more a center of campus attention. Community colleges provide a useful site for investigations regarding the role of leadership due to the consideration of the pending leadership crisis at these institutions (Evelyn, 2001), the demand-response nature of the college, and the ensuing organizational change resulting from responding to external demands (Gumport, 2003). Moreover, demographically, the number of women serving as presidents in these institutions (Glazer-Raymo, 1999) and the fact that community colleges enroll just under half of all undergraduate students in American higher education (Cohen \& Brawer, 2003) provide a unique context for investigation. Coupled with these issues is the financial context of community colleges. Institutionally, community colleges receive the lowest state funding per full-time equivalent student of all levels of public 
education (Gumport \& Jennings, 1999) and have been subject to cuts in the latest round of budget rollbacks (Arnone, 2003). Community college presidents, therefore, serve an important function in guiding these institutions in turbulent times. As college leaders, presidents act to help campus members create meaning during periods of uncertainty. An enhanced understanding of how these leaders construct their leadership provides a mechanism to comprehend this critical position on campus, and to consider avenues for professional development for future community college leaders.

In situations of uncertainty and change campus members seek to make sense of new events and obtain an understanding of how what they are experiencing connects with their past knowledge (Senge, 1990; Weick, 1995). College presidents are no exception. Weick (1995) notes that "sensemaking begins with the sensemaker" (p. 18). Thus, before college presidents can help others on campus understand and interpret events, they must first achieve a sense of understanding for themselves. The question guiding the research reported here concerned how community college presidents cognitively frame their leadership roles.

\section{Literature Review and Theoretical Framework}

The conceptual framework of this research was based on the seven properties of Weick's (1995) model for sensemaking. The first step for individuals as they begin the sensemaking process is grounded in identity construction and is self-referential. Each person possesses an underlying mental map that aids them in navigating through life and work. This schema of how the world operates guides "individual interpretations of the past and present and expectations for the future" (Harris, 1994, p. 310). Weick's second property deals with the retrospective nature of 
sensemaking. Here people use their past experiences to better understand how to relate to the most recent occurrence with which they are trying to make sense.

The third property in Weick's schematic involves enactment. In this scenario individuals are part of the organizational setting and as such, they have an influence on that environment. In the presidency, this feature is even more pronounced given the prominent visible and symbolic location of the president at the top of the organizational hierarchy. The fourth element of Weick's model deals with the social interaction of organizational members as they attempt to achieve an understanding of situations. Of particular interest here is the mediation through social discourse and conversation that helps shape ultimate meaning. Again, given the high level of intermingling of college presidents with institutional members and external constituents due to their position, the role of interaction is heightened and more visible compared to others on campus.

The fifth property of the model concerns the ongoing nature of sensemaking. There is not a definite beginning or end to the process, rather a continuous filtering and processing of information to obtain understanding. In the case of the president, information is multifaceted and comes from a wide variety of sources. The nature of individual schemas provides the basis for the sixth property of Weick's model. Extracted cues serve as a point of reference, and with past experience, guide interpretations (Markus, 1977, as cited in Harris, 1994). For example, when presidents conceptualize the classroom experience, they typically draw from a knowledge base that consists of typified roles for the professor, the students, and the ensuing classroom interactions. Similarly, college presidents have an expectation of the function of the faculty senate and other decision-making bodies on campus and of their role during these processes. 
Weick's last property pertains to the notion of situations being interpreted as the plausible versus accurate. Plausibility is grounded in the expected, credible outcome. When anticipating reasonable results, the details of reality are overshadowed by the expected reality. This last point reinforces Senge's (1990) conception of underlying mental maps guiding behavior and drawing inference from situations based on assumptions rather than breaking out of this mold and questioning the underlying schema guiding these actions.

The conceptual framework under girding this research used Weick's (1995) seven point model to better understand how community college presidents constructed their leadership. Given the role of college presidents in framing situations to aid campus members' reality (Amey, 1992; Eddy, 2003b; Fairhurst \& Sarr, 1996), it is critical to understand the antecedent to this process, namely how leaders first construct their own meaning.

\section{Methods}

Using the theoretical framework of sensemaking and its part in the construction of organizational reality builds on other studies of organizational culture (Bechler, 1995; Chaffee \& Tierney, 1988; Stevens, 1996; Tierney, 1991a; Tierney, 1991b), which used in-depth interviews and participant observations. The contextual nature of sensemaking and its emphasis on the meanings people attribute to their understanding of situations provided the basis of this phenomenological study. Phenomenology research searches for the central underlying meaning of an experience, in this case the construction of leadership by community college presidents, and uses data reduction to analyze specific statements and themes for possible meanings (Creswell, 1998). The focus of this research methodology on how individuals consciously 
develop meaning via social interactions (Creswell, 1998) intersects directly with Weick’s (1995) sensemaking framework.

A total of nine community college presidents were interviewed in the research reported here. Site visits were conducted at all locations, with face-to-face interviews occurring with all participants. The factors for the intentional selection of the study's community colleges included new presidents leading these institutions, geographic and institutional diversity, the occurrence of organizational change, and gender balance. Table 1 provides a summary of the site presidents' demographic information and a brief review to indicate the size and location of the community college. Annual student full-time equivalent (FTEs) enrollment indicates unduplicated student enrollment and is based on the measurement equivalent of one student enrolled full time for one academic year (IPEDS, 2004).

Upon completion of the site visits, all interviews were transcribed verbatim. For the research reported here, the transcripts were reviewed for elements that reflected the seven properties of Weick's (1995) sensemaking model. Transcribed interviews were read and re-read, obtaining a sense of overall themes. The presidents' statements were reviewed to discover how the participants constructed their ideals of leadership. Thematic groupings put assorted statements in separate categories that indicated various perspectives on how the participants framed leadership. Patterns and categories were identified and noted using what Marshall \& Rossman referred to as "reduction" and "interpretation" (as cited in Creswell, 1994, p. 154). An analysis of the themes served to highlight intersections of leadership construction with Weick's sensemaking model.

Insert Table 1 


\section{Findings}

The emerging themes from the interviews were juxtaposed with Weick's (1995) seven properties of sensemaking. The first theme, Constructing a Leader, corresponds with the first two properties of the sensemaking model, namely identity construction and retrospection. The second theme, Reflective Leadership, links with Weick's properties of enactment, social interaction, and on-going sensemaking. The final category, Road Map in the Presidency, covers the properties of extracted cues and plausibility versus accuracy. The following section expands on each of the main theme areas. Table 2 contains a summary of the links between the themes, the seven properties of Weick, and a summation from the interview analysis.

\section{Insert Table 2}

\section{Constructing a Leader}

At the core of how each of the presidents began to construct their leadership was the cognitive orientation of the respective president. In describing their campus leadership approach, the participants reviewed how they set about decision-making, worked toward collaborative campus relationships, and communicated on campus. In these vignettes, the underlying schemas or mental maps of the presidents became apparent. Some leaders described the ways in which they used symbolism on campus. For instance, Jones said, "You need to understand my leadership style. I guess I would classify myself as a visionary. I tend to be more creative.” In leading from this cognitive location, Jones discussed how he managed meaning on campus. "Now part of the change that I didn't dwell on, at no point did I dwell on the negatives or even really talk about them much....The new stuff became the focus...it seems a lot of the concerns one has become less important." Other participants used a more structural approach. Bett noted, 
"I do believe in the chain of command," and likewise Fields added, "I appointed two vice presidents right away - like the fall of my first year, when I realized I needed to get some space. I needed basically to get some control." Chipper used a collegial orientation in describing the development of a learning college approach at her institution, whereas Pauldine and White utilized a more political approach as they worked to gain resources for their campuses. White pointed out that his campus members felt like "the poor third cousin who had always been shortchanged in facilities and in budget and in personnel." Since White took over, he obtained through lobbying in the district a $37.5 \%$ boost in the campus budget. The central role of the underlying schemas and lenses used by each president was best summed up by Fields when she said, “I think I'm very frank...but I don't know any other way to be.”

Past experience served as a strong source of forming impressions about leadership and of how each participating president wanted to construct their own leadership. Some of the participants had strong mentoring relationship; others noted obvious shortcomings in this development area. For Richards, it was his mentor who encouraged him to seek a presidency. As he recounted, "She said, "Stanley, I think you have the potential to be a president one day so start thinking about that"....My mentor gave me opportunities to get skills that would prepare me for a presidency." Counter to this positive experience, Fields reflected on mistakes and surprises in her first year on campus: "I think that's a mistake people might make in their first presidency, particularly if they don't have a lot of mentoring, and I didn't.... just have a sense that some of my male colleagues have stronger mentoring arrangements than I did.”

Those who did not have a mentor encouraging them to consider a presidency had a stronger internal drive in seeking the position. Pauldine commented on this drive, 
I had a kind of epiphany about a year before I took this job....I was doing some consulting work at another community college and the president was struggling with his board and was struggling with faculty. You know when you do an assessment on enrollment you open Pandora's box. You get all of the dirty laundry and he asked me, "How should I handle this? Would you talk to the board?" and I thought, wow, I could be doing this job!

Likewise, Fields noted, "You find yourself watching your boss [the president] and thinking he's making mistakes that I wouldn't make." White agreed, “I started out as a faculty member teaching at a community college. But I quickly found out I wanted to fix it — there had to be a better way of running an organizational than the one I was teaching in.” Thus, as these individuals began to construct their ideals of leadership, they were making choices to either model the behaviors of those mentoring them or consciously choosing to not model the leaders in which they were in contact. In either case, past experience served as a strong learning tool.

Other positions outside of single campus administration served as another strong factor in the development of each individual's conceptions of leadership. Two of the presidents working in the multi-college district had district office or state oversight responsibilities that provided them with a more macro-view of leading within a system. Others had consulting background that allowed them to see experiences on campuses across the country or a state, whereas Lane even had a ten-year hiatus from higher education while working in government. Lane commented on his break from college administration and its impact on his leadership, saying, "I would have approached this job if I had been on a linear path, from faculty member to some sort of administrator or president, in a very different way." 
Leadership development programs were noted as a part of preparing for a presidency for some of the study participants. Two members noted attendance at the League for Innovation in the Community College's Executive Leadership Institute, while another obtained his doctorate in the community college leadership program at the University of Texas at Austin. As one participant reflected, "The summer [League] program helped with some networking and also clarified my thinking on what I really wanted to do and where I wanted to be." Another commented on how his mentor sponsored him for the Executive Leadership Institute, how during his attendance he met senior administrators from the college to which he was applying, and how he used this opportunity to network. The president who attended the UT program noted the benefits he received from the internship requirement since it provided the opportunity to see how others modeled effective leadership. None of the other participants focused on benefits they received from any type of development program, instead often noting the lack of these opportunities for them.

A part of how each individual experienced past and current opportunities was also based on gender. For the White males in the study, the ubiquitous aspect of their race or gender was not an obvious consideration in their underlying schemas since these characteristics matched the historical norms of leadership in community colleges. One of the male presidents even described his style as that of "the old country boy." All of the presidents in this study had long serving histories within the community college field, which influenced their perspectives regarding traditional male norms of leadership. The one president of color did not refer to any issues he faced due to his race or ethnicity, but was one of the leaders who emphasized the role of his mentor as he moved up the presidency. 
For some of the women presidents, however, gender played a larger role in how they saw themselves. As Pauldine commented above, she had not envisioned herself in the role of a college president. Moreover, the ways in which her gender intersects with her role as president were apparent when she recounted her first campus convocation,

I spoke in my first convocation piece that I was particularly well suited to this challenge because we had raised a family on a single faculty member's salary, since I didn't work when our children were young, but I was always pinching pennies and managing, so I was very well equipped for this job.

The reference to her role as wife and mother in a public campus speech highlights her conceptions of her gender in ways that the male counterparts in the study did not. The role of motherhood served a strong role for Fields as well as she recounts,

It was clear to me when my son was just three or four years old that I could not take an administrative position and protect what was important to me, which was the stability of my marriage and my son's growing up in a stable environment, so I left the associate dean's position.

Fields' later entry into higher level administrative positions was dictated by choices based on her family life. This fact coupled with her perceived lack of mentoring made Fields comment, "I knew I was going to have a rocky time."

As noted in table 2, the construction of leadership for the research participants was founded on their cognitive orientation and influenced by their past experiences. Each president used previous situations to alter and adjust their own schematic understandings. As Schmidt noted, "I know the business. It's difficult to work for someone who has been a vice-president of all of these areas like I have because I have a perception of what's right.” These presidents 
learned from both their good and bad experiences. In the case of the latter, negative role modeling served as an example of how not to lead or how not to make the same mistakes. The use of historical experiences allowed these leaders to continue to make sense out of what they witnessed. In their new capacities as institutional leaders, their perspective on the college has changed. As a result, they can interpret scenarios from this new location and obtain more insight, while continuously learning what it means to be a leader.

\section{Reflective Leadership}

As the presidents in this study described their leadership and their campuses, it was apparent that they were experiencing situated cognition. Situated cognition describes learning as it occurs within a context. Lattuca (2002) notes, "learning, then, is shaped not only by what happens between individuals in interaction, but by the cultural, historical, and social contexts in which their interaction is embedded" (p. 713). In general, new presidents enter an existing college setting steeped in history and with an established culture. While leaders have experiences upon which to draw as they take over the helm of the college, they need to learn how to lead within the particular context of their new college.

An obvious first learning experience centers on new leaders understanding whom they are following in the role of president. President Lane commented,

Someone encouraged me to read Birnbaum and one of the things he talks about is a key indicator for success of any college president at any level is coming after somebody who was not liked. I wouldn't say [the previous president] was not liked or was liked, but people were definitely tired of him....So, when you come 
into that kind of environment people are more receptive to change....This was the rogue campus before I came. That's why I'm here and that person's not.

Pauldine reflected, "Every campus goes through cycles where they have a president and there are a lot of good things about that president, but when the president leaves then they want to make sure that the bad things about that president aren't repeated." Similarly, Fields noted how many of the changes she was making on campus were in response to actions carried out by a previous president who was "a dictator." Thus, part of the learning for the new presidents was figuring out campus needs emanating from past college leadership and reacting to these priorities. For some of the new presidents, this meant being the "change agent"; for others, it meant "refinement of a mature institution" or maintaining "the collective wisdom."

As the presidents began to obtain a sense of their new campuses, they in turn started to enact changes in the campus environment. President Schmidt summed this up when stating, "I think leadership can change the environment. You have that impact." Each of the presidents in the study impacted their colleges. Several devised strategic plans that were being operationalized. Program reviews, organizational restructuring, new program development, and streamlining of campus policies were all outcomes under this group of new presidents. How the leaders chose to enact changes bore directly on their individual cognitive schemas. Those that were more structurally oriented made greater use of the campus hierarchy, whereas those who preferred symbolism paid more attention to managing meaning through logos, celebrations, and cultural change.

To obtain a sense of their institution's culture, most of the new presidents took time initially to meet with campus and community members. Richards recalled, "I told them [campus members] that I was going to do three things: look, listen, and learn. That's what I did." Pauldine 
hosted coffees for campus members, Lane held private meetings with all campus members, Schmidt and Jones conducted campus-wide strategic planning sessions, while Bett hosted monthly campus celebration afternoons.

Generally, interactions with campus members occurred in a number of ways. Jones noted, "Jack Welsh says that communication is the key. Honest and open and often. I struggle in this position, as do most academic presidents with the best vehicle to do that." When asked how they liked to communicate, many of the participating presidents replied that they preferred face-toface meetings and that they try to do these meetings as often as possible. Walking around the campus and being visible was one means to accomplish these interactions with campus members, although not always easily accepted. One president pointed out,

I frighten people when I walk around campus. What's she here for? What's she looking for? But I hope the more I do it the more accepted it will be. People will sometimes talk to me informally when you know they wouldn't set up a time.

In addition to these smaller meetings with faculty and staff, most campuses had some forum at the beginning of the year for all employees where a general state of the college address was given. Depending on the cognitive orientation of the president, these forums were more or less scripted and interactive. In either case, the key end product was that information was shared. All the presidents in this study also posted information on their websites, sent e-mails, or distributed written memos and policies. Again, the individual preferences of each president dictated the most frequent mode of communication.

In addition to information shared directly by the president, emissaries were used to relate news. One president noted, "A lot of communication goes down, not directly from me, it goes through other people." The chain of command was used to a larger extent by some presidents 
than others. Many of the presidents talked about being inclusive on their campuses, but it was not always obvious how campus members were able to convey information up the hierarchy. On some of the campuses the presidents described open planning sessions, "Our strategic planning sessions were interactive, more of a dialogue and smaller groups." As a result, this same president reflected, "From the sessions ideas emerged, not in purely the way I thought of them, but in expanded ways. So there was universal ownership. Much more universal ownership than the direction I wanted to go." Other presidents were less comfortable with such an open of a process and liked more structured sessions when involving the larger campus.

A critical component of how sitting presidents reflect on their leadership relates to their perception of the role of followers. As indicated, some of the study presidents established ways in which campus members could provide feedback on change initiatives and campus events. Whether in small or large group settings, these presidents sought feedback in some form to alter or expand initial plans. Jones commented, “Just because I had a vision, I couldn't implement it. I needed to do something before that. I needed to develop consensus. Consensus is the wrong term. I need to develop strong support for that from a group of faculty and staff." In this case Jones relied on getting a critical mass of followers to support his plans versus obtaining total consensus prior to moving forward. Others sought feedback through the use of "trusted faculty" or their "leadership cabinet." Regardless of the form of feedback, ultimately this advice was key to presidential learning and obtaining the desired outcomes.

All of these presidents were good at getting information out of the president's office and into the hands of campus members. The presidents had a perception of how much they in turn listened to the followers on campus and incorporated their ideas. Some, however, did not always share the presidents' perception, as recalled by one president. 
One of the things that came up in [the accreditation team's ] oral summary report was that they'd like to improve communication. And I just kind of smiled. Because I think that's probably something you say everywhere and I turned to somebody and I said, "Just tell me what I could do that I'm not doing." You know, I just couldn't even think of a single thing. I send memos out frequently dealing with state issues, budget issues, trying to inform, trying to educate. I attend the college senate meetings once a month and do a quick summary of what's going on. We do open forums. We have a weekly update in print and in electronic form for the internal campus community, and so, I kind a thought, Well, I'm willing, but I don't know what else I could do at this point.

The forms of communication that this president outlined were all top-down manners of dispersing information. In this example, the communication flows out of the president's office, but it is not clear how follower feedback was incorporated or sought. This may be the reason the accreditation team commented on the communication flow on this campus.

Clearly, each of the presidents was still learning about leadership on their campuses. Reflective leadership utilized Weick's (1995) properties of enactment, social interaction, and ongoing sensemaking (see Table 2) during the learning process. Interactions with campus members served to provide feedback to the new leaders on progress and links between actions and outcomes. Although each president held core beliefs that emanated from their cognitive orientations, these central tenants were augmented by experiences on campus. 


\section{Road Map in the Presidency}

The college presidents in this study constructed their leadership based on core elements of who they were as individuals, augmenting their learning with each new context in which they were placed. Social cognition for these leaders occurred within the unique context of their new campuses and related to how the presidents processed information given their cognitive orientation. The context included the immediate issues and the culture of each campus and the external context in which all institutions of higher education operate, e.g., changing student demographics, expanding faculty roles, budgetary constraints, etc.

Thus, the roadmap in the presidency is not static, but rather dynamic and changing. New information provides a learning opportunity for the president and ultimately, a change in response. As President Fields commented, "My self image is I like to work through other people, but they've got to be the right people!... That means that I haven't fixated or crystallized in any given mode and I try not to do that." Here Fields exemplifies the use of feedback loops involving campus members and how she allows herself the opportunity to have different responses to situations based on the unique situation and people involved.

President Chipper oversaw the opening of a new campus. This provided an opportunity as she stated, "We started with a blank page." A small start up team for the college conducted a needs assessment to determine the physical design of the campus, while simultaneously members sought best practices on a national scope. Chipper notes,

The vision came out of the ability to build a college from scratch in the $21^{\text {st }}$ century, taking best practice of everything we all wish we could do but can't because there's always limitations either by organizations or by people you have employed, or by habit, or by physical plant and to really then to take full 
advantage of the opportunity to take the blank page and actually build a learning college. We're not using that term, but we're really building a college around learning engagement.

The situated learning for Chipper is clearly unique compared to the other sitting presidents who are leading established campuses. During the planning stages the president and the executive team made all decisions collaboratively through consensus. As new members were added to the organization Chipper's goal was to have them accept the vision the executive team formulated for the new college. She cautioned, "A bigger challenge might be for us to be open to the new ideas that they [new college employees] will bring. And not to just say well, no, you can't do that because that's not the way we planned it." This vignette illustrates the tension all leaders have between taking what they believe and see as the best plan for the college and incorporating disparate perspectives.

The ways in which the presidents learned from their settings was dependent on how well they were able to extract cues, both during the interview process for the presidency and once on campus. Metaphorically, the cues served as sign posts giving directions on the leaders' road maps. Pauldine recalled her initial reactions to the campus, "I was struck by, people put a good front on, they put a good face on, but it was clear that there was some underlying cynicism or just a concern about how this campus was going to be viable." As a result of this interpretation, she began to construct her vision of what was needed from the campus leader. She said, "My initial impressions were that this was a campus that really needed, for a lack of a better term, a shot in the arm. Somebody who would inspire some trust and some confidence that this campus was going to be okay." Therefore, the road map Pauldine saw before her was drawn by her impressions of what she felt the campus needed. 
Another president had a different experience. This president described her first visit to campus for the interview and subsequent outcomes of the first year as follows:

Based on my own experience I went in not knowing the whole story. I think the board was trying to be honest with me. They should've sent clearer signals that what in retrospect were [cues]. But I just didn't have a clue until I got here. It was October before I realized the extent of trouble this college was going through. As a result of not being prepared for the particular reality she encountered once on campus, the first year was one of turmoil in which the president let several administrations go. The impact of this situation on the president's cognition was clear. She noted,

If I ever become a president again, you know the old saw about do you ask for written letters of resignation from all the senior staff?....I've always felt that was an inhumane and cruel and uncivilized way to move into a new job. Having had the experience I did here, I don't feel that way anymore.

The road map for this president was altered by the way in which she perceived the cues around her and the ultimate outcome of her first year experience. As a result, both the way in which this president constructs her leadership and the ways in which the campus members see her as a leader were impacted.

The findings from this study illustrate a wide range of leadership approaches. Some of the presidents interviewed considered themselves visionary and charismatic leaders. Others saw themselves as team players or servant leaders, whereas still others as the ultimate decisionmaker and leader for the campus. Each president had a different road map that they used while leading their campuses. The created road map made use of cues the presidents extracted, as well as, the ways in which they interpreted meaning from events (see Table 2). There was no one way 
to define or choose a most appropriate way of leading. As one president commented, "It was obvious to me that I was a good fit with the management team." It was the goodness of fit between each individual president and the needs of their campus that was more important for a successful presidency than any one particular way of being a leader. The experiences of each of the leaders on their campus, in turn, also impacted each president's underlying schemas or mental maps of what it means to be a leader.

\section{Discussion and Conclusion}

The findings from the research reported here highlight that college presidents are constantly learning and adjusting their conceptions of leadership. The foundation for this learning journey is the core schema of how each president processes incoming information and begins to make sense of it (Markus, 1977). This internal structure provides the framework, ultimately resulting in comments like those made by President Fields when stating, "I don't know any other way to be." A major component contributing to this orientation is past experiences and interpretations of these past experiences. As Schmidt said, "I know the business." Having served in many positions on other campuses, Schmidt had an opinion on what worked elsewhere and made the assumption that similar results likewise would be apparent in his new context. This sentiment was echoed by several of the other presidents as they recounted how changes they were putting into operation at their new colleges were similar to those previously implemented; comparable results were anticipated. The presidents' schemas, therefore, served as shorthand for them in understanding new situations.

Given that sensemaking is ongoing and that situated cognition occurs, as these presidents apply their past schemas in new situations they may begin to consider and learn from these 
alternatives. One of the ways in which this altered learning occurs is through the use of the feedback loops on campus. A limitation of the recall element of cognition, however, is that the automatic response to particular scenarios may foreclose consideration of alternatives or disregard potentially important auxiliary evidence, thus making feedback critical. As noted, some of the presidents hosted campus-wide sessions and used this feedback to modify their plans. Others relied on trusted insiders to provide feedback. A critical element of the feedback involves questioning of underlying assumptions (Argyis, 1992). Without questioning of the beliefs guiding the situation, it is difficult for deeper learning to occur. This type of reflection requires the leader to step back to obtain a macro view of the particular situation or "stand on a balcony" (Heifetz, 1994, p. 253). As President Pauldine commented about questions she had about campus processes, "Nobody ever asked those questions. So, the two things I heard were, you know, "We've always done it that way." "Well, nobody ever asked!'”' In this instance, she was questioning existing assumptions and pushing both her own and campus members' learning.

The role of past experiences was critical to the construction of leadership for the study participants. All of the presidents brought to their new positions years of experience in community colleges. Those with consulting backgrounds and other past administrative work in either a central office or other agency noted how these experiences influenced the ways in which they approached their leadership. As Lane said, "I would have approached this job [otherwise]...in a very different way." The ideal of obtaining as many and as varied work experiences contributes to constructions of leadership that are more complex. Similarly, as Bensimon (1989) found in her application of Bolman and Deal's (2003) four organizational lenses to determine how the participants in her study approached their leadership, the use of 
multi-frames increases effectiveness and provides for broader schemas from which to draw during a presidency.

Future research should focus on replication of these findings when presidents possess less background in the community college setting. A leader coming from a predominantly business background, for instance, may make sense of the new position of community college president quite differently. Similarly, geographic and college size differences of previous community college experiences adds to cultural differences that new presidents draw upon. In this research, several of the presidents held positions at different types of community colleges, e.g., rural, urban, suburban, than the college they now lead. Geographic moves for the presidents also allowed them the opportunity to gather experiences in different contexts. The diversity of these experiences adds to their ability to understand situations from multiple perspectives.

As learners, the college presidents were predisposed to a particular way of processing information and operating within an organization. Past experience informed the ways in which the presidents in the study interpreted current events on their campuses and what they saw as options or alternatives in the decision-making process. Mentors played a strong role for some in forming their perspectives, but more importantly in opening doors and providing opportunities. This critical role points out implications for future leadership development. Since many of the formal leadership development programs are dependent upon sponsorship, mentors and other senior administrators serve as gate keepers for those seeking leadership roles. Given the positive role these programs served for some of the participants in this research, it is critical to consider ways of expanding these leadership development opportunities. Of particular concern then are potential leaders without mentors or advocates. Community colleges may be missing a critical pool of applicants for the presidency due to lack of access to these formal programs. 
Formal leadership development programs were utilized by some of the study presidents in preparing for a presidency. The fact commented on most often in these recollections was not the sessions attended per se, but rather the networking opportunities and the reflection the participants underwent in determining why they wanted to seek a presidency. The implication of this finding highlights the role of exposure to others as another factor in the learning process. In this case, the feedback is not from campus followers, but from colleagues and mentors. The presidents augmented their own experiences with the experiences of others and how other colleagues approached and handled problems. Learning, and ultimately one's construction of leadership, was supported and influenced by hearing about different experiences. Given the isolating elements and lack of peer leaders on an individual campus, networking opportunities with others in similar positions provided another learning opportunity.

The ways in which college presidents construct their conceptions of leadership has repercussions. Since leaders often frame reality for others on campus (Neumann, 1995; Smircich \& Morgan, 1982), how leaders first construct meaning for themselves influences how they in turn construct meaning for others. Presidential learning is based on the situated cognition that occurs during their administration, the feedback of followers, and on-going sensemaking of cues. Without reflection or campus feedback, leaders may not learn as much or adjust their leadership to be most effective in the given context.

Given the fact that both the president and campus members construct leadership, college presidents have some control over how they present themselves to their campus members. How these leaders communicate the interpretation of events to the campus and how they frame situations influence the meaning interpreted. As noted, the presidents used a variety of formats to communicate with campus members, including campus-wide forums, face-to-face meetings, 
written publications, and electronic media. The presidents' cognitive schemas predisposed them to prefer one mode of communicating over another.

The constant telling and re-telling of a particular interpretation of events begins to make this the accepted version. Concentrating on the perspectives that are critical to the presidents' mission and vision begins to form campus reality. Thus, it is critical for presidents to reflect on how they wish to use various routes of communication to reinforce their message. Certainly, their past experiences serve to guide choices; however, it is important for leaders to consider how these previous settings and outcomes may also limit current choices.

Perhaps the most significant finding from this study is that there is no one way for leaders to learn about leadership, just as there is no one way of leading. The broad spectrum of ways in which college presidents successfully lead their campuses begins to break down the conception of more narrowly defined and acceptable ways of leading. This point is particularly important for leaders who do not match the historical definitions of a community college leader, namely a White male. Women in this study, however, still highlighted the binds they faced in climbing the hierarchy and finding an authentic way to lead. The sole minority member in this study did not comment on issues of race in his leadership, but did note the aid he received from his mentoring experience. Mentoring and breaking down singular definitions of leadership begin to open up opportunities for previously excluded groups. Given the role of experiences in guiding leadership construction, it is critical that women and people of color seeking leadership positions gain as many varieties of experiences and network to obtain sources of support during their quests for a presidency.

In summary, the research reported here identifies several components that community college presidents utilize in constructing their conception of leadership. The individual cognitive 
orientation, past experience, mentoring, situated cognition, feedback loops, and social interaction were all critical components to the learning experience. Knowing the importance of these factors can allow campus leaders an opportunity to be reflective about the choices they make in professional development and consider how they approach new leadership opportunities.

Moreover, as incumbent presidents mentor other prospective leaders, they can provide a variety of experiences for these budding leaders that can be drawn on in the future. 


\section{References}

Amey, M. J., \& Twombly, S. B. (1992). Revisioning leadership in community colleges. The Review of Higher Education, 15(2), 125-150.

Amey, M. J. (1992). Cognitive constructions of leadership. Paper presented at the Annual Meeting of the Association for the Study of Higher Education.

Argyris, C. (1992). On organization learning. Cambridge, MA: Blackwell.

Arnone, M. (2003). Students face another year of big tuition increases in many states. The Chronicle of Higher Education, 49(49), A24.

Bechler, C. (1995). Looking beyond the immediate crisis response: Analyzing the organizational culture to understand the crisis. Journal of the Association for Communication Administration, January, 1-17.

Bensimon, E., Neumann, A., \& Birnbaum, R. (1989). Making sense of administrative leadership: The "L" word in higher education (ASHE-ERIC Higher Education Report No. 1 ED 316 074 MF-01; PC-05). Washington, D.C.: The George Washington University, Graduate School of Education and Human Development.

Birnbaum, R. (1992). How academic leadership works: Understanding success and failure in the college presidency. San Francisco: Jossey-Bass Publishers.

Blevins, V. B. (2001). Women presidents define the college culture through story. Community College Journal of Research and Practice, 25, 503-516.

Chaffee, E. E., \& Tierney, W. G. (1988). Collegiate culture and leadership strategies. New York: Macmillan.

Coates, J. L. (1992). Situational leadership: A study of the perceived leadership styles of deans of students at selected liberal arts colleges. Unpublished dissertation. East Lansing: Michigan State University.

Cohen, A. M., \& Brawer, F. B. (2003). The American community college (4th ed.). San Francisco: Jossey-Bass Publishers.

Creswell, J. W. (1994). Research design: Qualitative \& quantitative approaches. Thousand Oaks, CA: Sage Publications, Inc.

Creswell, J. W. (1998). Qualitative inquiry and research design: Choosing among five traditions. Thousand Oaks, CA: Sage Publishers.

Eddy, P. L. (2003a, April). The impact of presidential cognition on framing organizational change. Peer reviewed paper presented at the 2003 Annual meeting of the Council for the Study of Community Colleges in Dallas, TX. 
Eddy, P. L. (2003b). Sensemaking on campus: How community college presidents frame change. Community College Journal of Research and Practice, 27(6), 453-471.

Evelyn, J. (2001). Community colleges face a crisis of leadership. The Chronicle of Higher Education (April 6, 2001), A36.

Fairhurst, G. T., \& Sarr, R. A. (1996). The art of framing: Managing the language of leadership. San Francisco: Jossey-Bass Publishers.

Fischer, J. L. (1984). The power of the presidency. New York: American Council on Education MacMillian Publishing Company.

Gillett-Karam, R. (Ed.). (2001). Special issue on women in community college leadership. Community College Journal of Research and Practice, 25(35).

Glazer-Raymo, J. (1999). Shattering the myths: Women in academe. Baltimore, MD: The Johns Hopkins University Press.

Gumport, P. J. (2003). The demand-response scenario: Perspectives of community college presidents. In K. M. Shaw \& J. A. Jacobs (Eds.), Community colleges: New environments, new directions. The Annals of The American Academy of Political and Social Science, 586 , 38-61. Thousand Oaks, CA: Sage Publications.

Gumport, P. J., \& Jennings, J. (1999). Financial challenges in public higher education: A trend analysis (Technical report for the U.S. Department of Education. no. NCPI-1320). Stanford, CA: National Center for Postsecondary Improvement.

Harris, S. G. (1994). Organizational culture and individual sensemaking: A schema-based perspective. Organization Science, 5(3), 309-321.

IPEDS. (2004). Retrieved from http://nces.ed.gov/ipeds/glossary/

Lattuca, L. R. (2002). Learning interdisciplinarity: Sociocultural perspectives on academic work. The Journal of Higher Education, 73(6), 711-739.

Leslie, D., \& Fretwell, E. E., Jr. (1996). Wise moves in hard times: Creating \& managing resilient colleges \& universities. San Francisco: Jossey-Bass Publishers.

Lovett, C. M. (2002). Tough times for colleges demand structural changes. The Chronicle of Higher Education, 49(8), B12.

Markus, H. (1977). Self-schemata and processing information about the self. Journal of Personality and Social Psychology, 35, 63-78. 
Neumann, A. (1995). On the making of hard times and good times. Journal of Higher Education, 66(1), 3-31.

Nidiffer, J. (2001). Leadership for a new century: Women's contribution to leadership in higher education. In J. Nidiffer \& C. T. Bashaw (Eds.), Women administrators in higher education (pp. 101-131). Albany: State University of New York.

Pfeffer, J. (1991). The ambiguity of leadership. In M. Peterson (Ed.), Organization and Governance in Higher Education (4th Ed., pp. 345-354). Needham Heights, MA: Simon \& Schuster Custom Publishing.

Roueche, J. E., Baker, G. A, \& Rose, R. R. (1989). Shared vision: Transformational leadership in American community colleges. Washington, DC: Community College Press.

Saenz, M. (1996). Leadership_-What it is. Community College Journal, , 16.

Senge, P. M. (1990). The fifth discipline: The art and practice of the learning organization. New York: Doubleday.

Smircich, L., \& Morgan, G. (1982). Leadership: The management of meaning. The Journal of Applied Behavioral Science, 18(3), 257-273.

Stevens, L. (1996). Case study of the role of organization culture in a community-technical college merger. Unpublished Dissertation, Columbia University Teachers College, New York.

Tierney, W. G. (1991a). Organizational culture in higher education: Defining the essentials. In M. W. Peterson (Ed.), Organization and governance in higher education (4th Edition ed., pp. 126-139). Needham Heights, MA: Simon \& Schuster Custom Publishing.

Tierney, W. (1991b). Symbolism and presidential perceptions of leadership. In M. Peterson (Ed.), Organization and governance (4th Ed., pp. 432-440). Needham Heights, MA: Simon \& Schuster Custom Publishing.

Tsunoda, J. S. (2001). All this and heaven, too? A divided life, but only one me! Community College Journal of Research and Practice, 25(3?), 171-180.

Vaughan, G. B. (1989). Leadership transition: The community college presidency. New York: American Council on Education, MacMillan Publishing Company.

Weick, K. E. (1995). Sensemaking in organizations. Thousand Oaks, CA: Sage Publications. 
Table 1. Participant and Institutional Demographics

\begin{tabular}{|c|c|c|c|c|}
\hline $\begin{array}{l}\text { President* } \\
\text { Location }\end{array}$ & $\begin{array}{l}\text { Campus* } \\
\text { Presidency }\end{array}$ & $\begin{array}{l}\text { Year Began } \\
\text { at this Campus }\end{array}$ & Presidencies** & $\begin{array}{c}\text { Annual } \\
\text { Student } \\
\text { FTEs }\end{array}$ \\
\hline $\begin{array}{l}\text { Jon Schmidt } \\
\text { (White Male) }\end{array}$ & $\begin{array}{l}\text { South Western } \\
\text { (suburban) }\end{array}$ & 1996 & $2^{\text {nd }}$ & 4000 \\
\hline $\begin{array}{l}\text { Christopher Jones } \\
\text { (White Male) }\end{array}$ & $\begin{array}{l}\text { Middle State } \\
\text { (rural) }\end{array}$ & 1998 & $2^{\text {nd }}$ & 3000 \\
\hline $\begin{array}{l}\text { Karen Fields } \\
\text { (White Female) }\end{array}$ & $\begin{array}{l}\text { Western State } \\
\text { (suburban, rural }\end{array}$ & $\begin{array}{l}1999 \\
\text { nches) }\end{array}$ & $1^{\mathrm{st}}$ & 2100 \\
\hline $\begin{array}{l}\text { Lynne Pauldine } \\
\text { (White Female) }\end{array}$ & $\begin{array}{l}\text { Eastern State } \\
\text { (rural) }\end{array}$ & 1999 & $1^{\mathrm{st}}$ & 2500 \\
\hline \multicolumn{5}{|c|}{ Part of a suburban five-college district located in the South } \\
\hline $\begin{array}{l}\text { Susan Bett } \\
\text { (White Female) }\end{array}$ & South \#1 & 1999 & $1^{\text {st }}$ & 7000 \\
\hline $\begin{array}{l}\text { Tracy Chipper } \\
\text { (White Female) }\end{array}$ & South \#2 & 2000 & $2^{\text {nd }}$ & $3500 * * *$ \\
\hline $\begin{array}{l}\text { Stanley Richards } \\
\text { (Black Male) }\end{array}$ & South \#3 & 2000 & $2^{\text {nd }}$ & 10000 \\
\hline $\begin{array}{l}\text { Harry White } \\
\text { (White Male) }\end{array}$ & South \#4 & 2001 & $2^{\text {nd }} * * * *$ & 7500 \\
\hline $\begin{array}{l}\text { Brian Lane } \\
\text { (White Male) }\end{array}$ & South \#5 & 2002 & $1^{\text {st }}$ & 7000 \\
\hline
\end{tabular}

*All participant and institutional names are pseudonyms.

**Includes current presidency

***Branch campus opened in Fall 2002, with full campus open in Fall 2003 and enrollment projections of 7000

$* * * *$ Also served in five interim presidencies. 
Table 2. Themes for Framing Leadership

\begin{tabular}{|c|c|c|}
\hline $\begin{array}{l}\text { Findings/ } \\
\text { Themes }\end{array}$ & $\begin{array}{c}\text { Weick's (1995) } \\
\text { Sensemaking Properties }\end{array}$ & $\begin{array}{c}\text { Support Evidence from } \\
\text { Participant Interviews }\end{array}$ \\
\hline \multirow{2}{*}{ 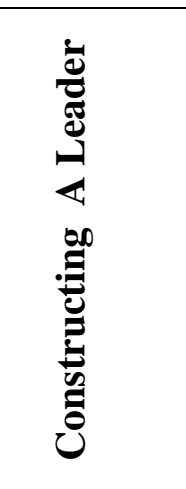 } & Pt. 1-Identity construction & $\begin{array}{ll}\text { - } & \text { Disciplinary background } \\
\text { - } & \text { Past experiences } \\
\text { - } & \text { External influences } \\
& \text { Cognitive orientation } \\
\end{array}$ \\
\hline & Pt. 2-Retrospective & $\begin{array}{ll}\text { - } & \text { Critical incident } \\
\text { - } & \text { Mentoring experiences } \\
\text { - } & \text { Reflective of past experiences } \\
\text {. } & \text { Reinforcement of success } \\
\end{array}$ \\
\hline \multirow{3}{*}{ 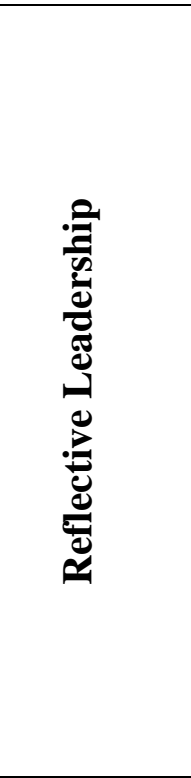 } & Pt. 3-Enactment & 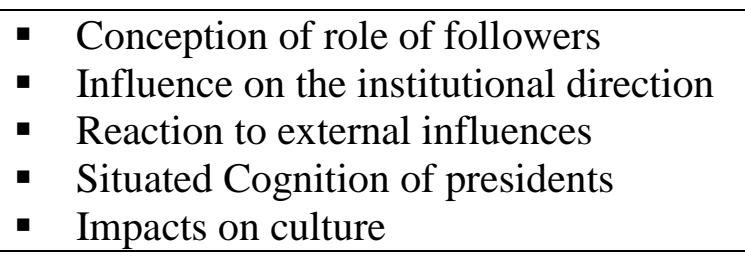 \\
\hline & Pt. 4-Social interaction & $\begin{array}{l}\text { - Preferences for communication } \\
\text { - } \text { Use of symbolism } \\
\text { - } \text { Relationship with leadership cabinet } \\
\end{array}$ \\
\hline & $\begin{array}{l}\text { Pt. 5-Ongoing } \\
\text { sensemaking }\end{array}$ & $\begin{array}{l}\text { - } \text { Adjustments to plans } \\
\text { - } \text { Role of campus feedback } \\
\text { - } \text { Use of environmental scanning } \\
\text { - } \text { Trusted to external influences } \\
\text { - } \text { Past experience guides present } \\
\end{array}$ \\
\hline \multirow{2}{*}{ 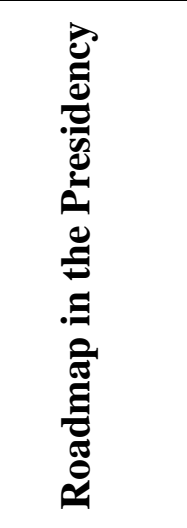 } & Pt. 6-Extracted cues & $\begin{array}{l}\text { - } \text { Influence of schemas on interpretation } \\
\text { - }\end{array}$ \\
\hline & $\begin{array}{l}\text { Pt. 7—Plausible versus } \\
\text { accurate }\end{array}$ & $\begin{array}{l}\text { - Interpretation of reality } \\
\text { - } \text { Ase of campus checks for accuracy } \\
\text { - } \text { Limits of position/isolation of president } \\
\text { - President's expectations }\end{array}$ \\
\hline
\end{tabular}

